\title{
Inhibition of copepod grazing by diatom exudates: a factor in the development of mucus aggregates?
}

\author{
Alenka Malej ${ }^{1}$, Roger P. Harris ${ }^{2}$ \\ ${ }^{1}$ Marine Biological Station Piran, Institute of Biology, University of Ljubljana, Fornače 65, 66330 Piran, Slovenia \\ ${ }^{2}$ Plymouth Marine Laboratory, Prospect Place, Plymouth PL1 3DH, United Kingdom
}

\begin{abstract}
Dissolved polymers, especially polysaccharides, are thought to play an important role in formation of larger organic aggregates in the sea. Phytoplankton may exude considerable quantities of polymers, although the particular conditions conducive to release of these substances are not known. Such processes are implicated in the formation of large-scale gelatinous mucus aggregations in the Adriatic Sea. We investigated extracellular carbohydrate release in the diatoms Coscinodiscus granii Stephanopyxis palmeriana, Skeletonema costatum, Nitzschia delicatissima, Thalassiosira weissflogii, and 2 species of Chaetoceros, under different culture conditions, and examined whether these exudates interfered with copepod grazing. The copepod species studied are typical of Adriatic coastal enviroments. Our results indicate that during the exponential growth phase the contribution of the high-molecular-weight carbohydrate (HMWCHO) fraction to extracellular release was minor, except in phosphorus limited medium. A shift towards an increased significance of HMWCHO was observed in the stationary phase for all species tested. Grazing experiments with Temora longicornis and Pseudocalanus elongatus demonstrated that copepod feeding was inhibited by HMWCHO diatom exudate and also stationary phase culture filtrate. Feeding rates were also adversely affected by the presence of pure HMW dextran used as a model substance. Copepod feeding was more strongly inhibited by diatom HMWCHO exudates than an equivalent concentration of pure dextran, suggesting an additional response to the chemical stimuli of algal exudates
\end{abstract}

\section{INTRODUCTION}

Evidence has accumulated that both healthy and stressed phytoplankton may release considerable amounts of organic compounds, among which carbohydrates are quantitatively important (Fogg 1983, Myklestad et al. 1989). High-molecular-weight carbohydrates represent the main constituent of slime secretion of phytoplankton and bacteria (Decho 1990) and have been shown to be involved in the attachment of cells to surfaces and cell-cell adhesion, producing multicellular aggregates (Yoshida 1991). Interparticle bridging by polysaccharide polymers is thought to be important in formation of larger organic aggregates in the sea (Alldredge \& McGillivary 1991).

Some phytoplankton species, particularly dinoflagellates, have been shown to produce compounds which deter copepod feeding (Huntley 1982, Huntley et al. 1986, Uye \& Takamatsu 1990) although the chemical nature of the specific compounds has not been identified. Exudates produced during phytoplankton blooms may interfere with copepod grazing. Chemically or mechanically mediated inhibition of grazing upon mucilage producing plankton may thus have potential significance for particle aggregation processes. Increased particle attachment due to algal exudates (Alldredge \& Silver 1988) together with specific combinations of physical conditions in the pelagic environment (Riebesell 1991) may also contribute significantly to macroaggregate formation.

Several recent studies have dealt with macroaggregate formation in different coastal and open waters; however, gelatinous (mucus) aggregates in some Mediterranean regions (Adriatic Sea, Thyrrenian Sea, Aegean Sea) have attracted special attention due to their widespread and massive appearance (Stachowitsch et al. 1990). Historical records of such occurrences date back to the 18th and 19th centuries (Fonda 
Umani et al. 1989, Molin et al. 1992) so eutrophication can hardly be considered as a direct cause of the mucus phenomenon. Several authors have tried to explain the phenomenon either by a microbial approach to 'solve the mystery of floating mucilage' (Herndl et al. 1992), by analysing the biochemical (Malej \& Faganeli 1988, Marchetti et al. 1989, Posedel \& Faganeli 1991) and the phytoplankton composition (Revelante \& Gilmartin 1991, Cabrini et al. 1992) of mucus, or by analysing environmental factors before and during the outbreaks (Fanuko \& Turk 1990). None of these explanations has proved convincing.

The purpose of our study was to estimate the extracellular carbohydrate release in selected diatom cultures under different culture conditions. The species studied were from the genera Nitzschia, Skeletonema and Chaetoceros, which have been shown to be associated with the formation of aggregates in the Adriatic (Marchetti et al. 1989, Stachowitsch et al. 1990, Revelante \& Gilmartin 1991), and were in most cases isolated from the field. In addition Coscinodiscus granii and Stephanopyxis palmeriana were studied as representatives of larger diatoms, as the former in particular has been shown to produce mucilage in situ and in culture (Boalch \& Harbour 1977). Isochrysis galbana and Tetraselmis suecica were considered as representatives of the microflagellates, which have also been associated with mucilage in the field (Stachowitsch et al. 1990). We then carried out a series of feeding experiments to examine whether these exudates interfere with grazing of copepods. The copepod species used, Temora longicornis and Pseudocalanus elongatus, are frequent species in the coastal zone of the Adriatic, and also in open waters, while Calanus helgolandicus is less abundant and typical of the winter spring period (Fonda Urmani et al. 1993). To test the thickening (mechanical) effect of polysaccharides we also examined the influence of pure high-molecular-weight carbohydrates on copepod feeding. The importance of these processes in largescale mucus accumulations is discussed.

\section{MATERIALS AND METHODS}

Phytoplankton cultures. Stock cultures of the diatoms Coscinodiscus granii and Stephanopyxis palmeriana from the Plymouth Marine Laboratory Culture Collection were maintained in $\mathrm{f} / 2$ medium (Guillard \& Ryther 1962) in batch culture using a 2 wk transfer cycle. For experiments, diatoms were grown in $3 \mathrm{I}$ Pyrex flasks containing $2.5 \mathrm{l}$ of prefiltered sterile $(0.22 \mu \mathrm{m})$ medium of 3 different strengths: $f / 2_{i} f N_{10} / P_{50}$ (N/P atomic ratio 122, referred to as P-lim); and $f / 200$. Cultures were not aerated, but were gently agitated manually once per day. The culture temperature was $14^{\circ} \mathrm{C}$ with a light: dark cycle of $12: 12 \mathrm{~h}$. The cultures in $\mathrm{f} / 2$ medium were exposed to 2 different light (coolwhite fluorescent tubes) conditions: high light (105 $\mu \mathrm{E}$ $\left.\mathrm{m}^{-2} \mathrm{~s}^{-1} ; \mathrm{f} / 2 \mathrm{HL}\right)$ and low light $\left(46 \mu \mathrm{E} \mathrm{m}^{-2} \mathrm{~s}^{-1} ; \mathrm{f} / 2 \mathrm{LL}\right)$ while the others were kept at low light conditions.

Two species of Chaetoceros, and Skeletonema costatum and Nitzschia delicatissima, were isolated from samples collected in March 1991 from the Gulf of Trieste (northern Adriatic). Cultures were kept in $f / 2$ medium at low and high light; otherwise the conditions were the same as for Coscinodiscus granii and Stephanopyxis palmeriana cultures. All experiments were carried out in duplicate.

Samples for cell counts and for extracellular carbohydrate analyses were collected approximately every $48 \mathrm{~h}$ for Coscinodiscus granii and Stephanopyxis palmeriana and daily for Chaetoceros species. $C$. granii and S. palmeriana cells were enumerated, after fixation in Lugol's solution by inverted microscope using the Utermöhl method, while Chaetoceros concentrations were determined with a Coulter Multisizer. Cell count data were used to define the growth curve for each species, and these were used to separate the sampling into the exponential and stationary phases. Samples from Skeletonema costatum, Nitzschia delicatissima and Thalassiosira weissflogii cultures were withdrawn only twice: during the exponential growth and stationary phase

Chemical analyses. For extracellular carbohydrate analysis, aliquots $(4 \times 50 \mathrm{ml})$ were first centrifuged $(4500 \times g ; 45 \mathrm{~min})$ to remove cells, and then the supernatant containing water soluble components was analysed for total carbohydrate (TCHO). The highmolecular-weight fraction (HMWCHO) was further determined after dialysis (12000 MW cutoff; Visking dialysis tubing) against distilled water ( $>36 \mathrm{~h}$ ).

High- and low-molecular-weight fractions of dissolved $\mathrm{CHO}$ exudate were also separated by gel filtration on PD-10 Sephadex columns (Pharmacia Corp.). Elution curves of standards (blue dextran with molecular weight of 2000000 , FITC dextran with MW 35600 and 4400, glucose, saccharose, and $\mathrm{CoCl}_{2}$, Sigma Chemical Comp.) are shown in Fig. 1. Samples for gel filtration from Skeletonema costatum cultures were taken 4 times: on Days 2, 5,8, and 28. Two non-diatom cultures (Isochrysis galbana and Tetraselmis suecica) in a stationary growth phase maintained under the same conditions as diatoms ( $f / 2$ medium, low light) were also analyzed. Total, and high-molecular-weight, dissolved carbohydrates were determined using the phenol-sulphuric acid reaction with glucose as a standard (Strickland \& Parsons 1968). Larger volumes (9 l) of stationary diatom cultures were centrifuged $(4500 \times$ g, $45 \mathrm{~min}$ ), supernatant dialysed against distilled water to isolate HMW components, the solution concentrated 
at 80 to $90^{\circ} \mathrm{C}$ under reduced pressure and used as an addition in the grazing experiments.

Carbohydrate release rates were calculated from a combination of cell counts and $\mathrm{CHO}$ analyses for time points during exponential and stationary growth phases. Two replicate determinations were made for each species for 4 time intervals during exponential phase, and 2 intervals during stationary phase. The possible influence of bacteria was investigated in initial experiments in which cultures were treated with $30 \mu \mathrm{g} \mathrm{ml}^{-1}$ of streptomycin. No significant differences were observed compared to untreated controls

Grazing experiments. The copepods Temora longicornis, Pseudocalanus elongatus and Calanus helgolandicus were sorted from zooplankton samples collected with a $250 \mu \mathrm{m}$ net off Plymouth. Copepods were starved overnight at $14^{\circ} \mathrm{C}$ in filtered seawater prior to experimentation. Grazing experiments were done at 13 to $14^{\circ} \mathrm{C}$ under dim light using triplicate $250 \mathrm{ml}$ glass bottles containing 20 ( $T$. longicornis or $P$. elongatus) or 5 ( $C$. helgolandicus) copepods for each treatment. The bottles were placed together with controls, containing only food suspensions, on a plankton wheel ( $1 \mathrm{rpm})$. The duration of the experiments ranged from $4 \mathrm{~h}$ (experiments with dextran) to $6 \mathrm{~h}$ (experiments with cell-free stationary phase medium). Feeding rates were calculated from the difference between initial $\left(C_{0}\right)$ and final $\left(C_{t}\right)$ particle concentrations determined with a Coulter Multisizer using the equations of Marin et al. (1986). Analyses of initial and final particle concentrations in control bottles showed no significant difference, therefore no correction for algal growth was necessary.

In a preliminary experiment, a mixture of adult Temora longicornis and Pseudocalanus elongatus $(10$ of each species) were used as grazers and Thalassiosira weissflogii offered as food (Plymouth Marine Laboratory culture collection, average cell volume $1255 \mu^{3}$ ). Feeding bottles contained either food suspension of algal cells (average food concentration $2845 \times 10^{3} \mu \mathrm{m}^{3} \mathrm{ml}^{-1}$, ca 2000 cells $\mathrm{ml}^{-1}$ ) in filtered seawater or food suspension with the addition of HMW$\mathrm{CHO}$ concentrate obtained from Coscinodiscus granii cultures (final HMWCHO concentration of approximately $4 \mathrm{mg} \mathrm{l}^{-1}$ ). Fecal pellets produced were pipetted into a counting tray and counted to provide an additional indication of grazing activity. Further grazing experiments were carried out to check the possible effects on copepod feeding of pure high-molecularweight carbohydrate using dextran MW 40000 (Sigma Chemical Co.) at concentrations of 4 and $20 \mathrm{mg} \mathrm{l}^{-1}$, and also the influence of $\mathrm{HMWCHO}$ (concentrate from C. granii culture; final concentrations in HMWCHOtreated bottles $=3.6 \pm 0.5 \mathrm{mg} \mathrm{l}^{-1}$; control bottles $<1 \mathrm{mg}$ $1^{-1}$ of total $\mathrm{CHO}$ ). Copepods used in this experiment were 20 adult $T$. longicornis or $5 \mathrm{C}$. helgolandicus per
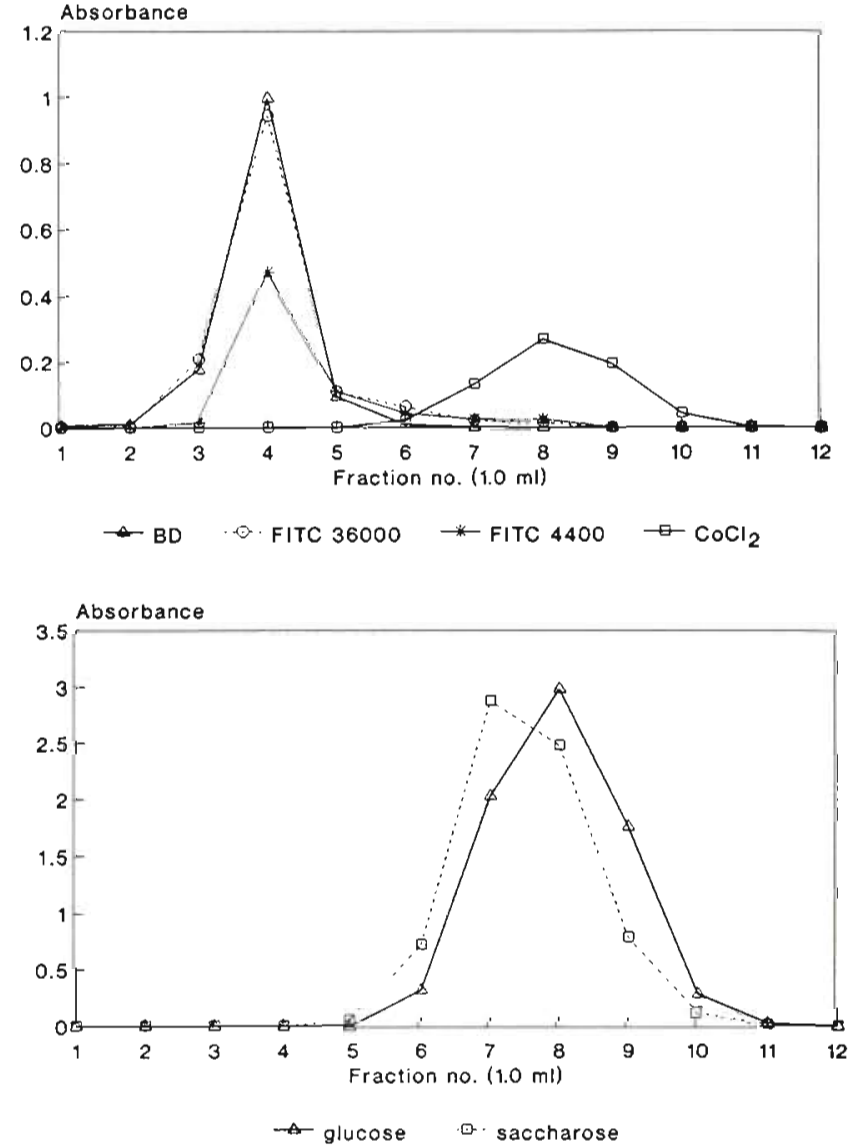

Fig. 1. Elution curves of standards: Sephadex gel-fractionation of high-molecular-weight dextran $(B D=$ blue dextran with MW 2000000 , FITC = fluorescein isothiocyanate dextran with MW 36000 and 4400) and $\mathrm{CoCl}_{2}$ (upper panel), and saccharose and glucose (lower panel). $x$-axis shows spectrophotometer reading for carbohydrates following standard methods for $\mathrm{CHO}$ determination

$250 \mathrm{ml}$ bottle. The experiment was carried out the same way as the previous one, offering $T$. weissflogii as a food (average food concentration $5800 \times 10^{3} \mu^{3}$ $\mathrm{ml}^{-1}$, ca 4100 cells $\mathrm{l}^{-1}$ ). Fecal pellets were counted and the length and width measured for 20 , selected randomly from each feeding bottle.

Finally, we tested the effect of algal exudate on Temora longicornis feeding using cell-free culture medium from a stationary Skeletonema costatum culture. The algal food ( $S$. costatum isolated from the Gulf of Trieste samples; average food concentration $4180 \times$ $10^{3} \mu \mathrm{m}^{3} \mathrm{l}^{-1}$, ca 14900 cells $\mathrm{l}^{-1}$ ) was suspended either in filtered seawater or in a filtrate containing algal exudates of a stationary culture of the same species. An additional experiment (average food concentration 7140 $\times 10^{3} \mu \mathrm{m}^{3} \mathrm{I}^{-1}$, ca 24500 cells $\mathrm{I}^{-1}$ ) was carried out with a $50 \%$ dilution of exponentially growing $S$. costatum culture medium and $50 \%$ dilution of stationary S. costatum culture medium. 
Table 1. Rates of TCHO release $\left(\mu \mathrm{g}\right.$ TCHO $\left.\times 10^{-7} \mu \mathrm{m}^{-3} \mathrm{~d}^{-1}\right)$ for different diatom species harvested in exponential growth phase (see 'Materials and methods' for details of culture media), and normalized to cell volume

\begin{tabular}{|c|c|c|c|c|c|}
\hline Species & Volume $\left(\mu \mathrm{m}^{3}\right)$ & $\mathrm{f} / 2 \mathrm{LL}$ & $\mathrm{f} / 2 \mathrm{HL}$ & P-lim & $\mathrm{f} / 200$ \\
\hline Coscinodiscus granii & $2.2 \times 10^{6}$ & 1.2 & 0.5 & 0.6 & 0.8 \\
\hline Stephanopyxis palmeriana ${ }^{a}$ & $1.7 \times 10^{5}$ & 1.3 & 0.3 & 0.5 & 0.8 \\
\hline Skeletonema costatum ${ }^{\mathrm{a}, \mathrm{b}}$ & $0.28 \times 10^{3}$ & 16.7 & 8.6 & - & 0.9 \\
\hline Nitzschia delicatissima a o & $0.1 \times 10^{3}$ & 12.1 & 4.7 & 1.0 & 2.0 \\
\hline Chaetoceros sp. 1 a, b & 50 & 5.9 & 2.5 & 2.4 & - \\
\hline Chaetoceros sp. $2^{a, b}$ & $2.3 \times 10^{3}$ & 0.4 & - & 0.2 & - \\
\hline Thalassiosira weissflogii b & $1.3 \times 10^{3}$ & 0.6 & 0.4 & - & - \\
\hline
\end{tabular}

\section{RESULTS}

The rates of TCHO release for different diatom species harvested during exponential growth and normalized to cell volumes are given in the Table 1 and the proportion of the HMWCHO in exponential and stationary phase in Table 2 . TCHO release rates during exponential growth varied from $<1$ to $16.7 \times 10^{-7} \mu \mathrm{g}$ TCHO $\mu \mathrm{m}^{-3} \mathrm{~d}^{-1}$. Skeletonema costatum, Nitzschia delicatissima and one species of Chaetoceros produced significantly more $(\mathrm{p}<0.01)$ soluble TCHO per unit cell volume than the other diatom species, the amounts being higher in high nutrient medium. TCHO concentrations over time in $\mathrm{f} / 200$ and P-lim culture media were generally proportional to cell numbers (Fig. 2), indicating that extracellular TCHO release took place in all growth phases. In $\mathrm{f} / 2$ media (LL and HL) the
TCHO concentration initially increased with increasing cell numbers, but ultimately reached a plateau.

During the initial growth period the contribution of the high-molecular-weight fraction was minor except in the P-limited medium. A higher proportion of HMW$\mathrm{CHO}$ fraction was also observed in $\mathrm{f} / 2$ medium under high light conditions for Coscinodiscus granii and Stephanopyxis palmeriana, while a shift towards an increased significance of $\mathrm{HMWCHO}$ was observed in the stationary phase for all species tested (Table 2). Gel permeation chromatography of soluble extracellular carbohydrates also showed an increasing importance of the HMWCHO fraction with ageing of the culture of Skeletonema costatum (Fig. 3a) and in the stationary cultures of Isochrysis galbana and Tetraselmis suecica (Fig. 3b). Small quantities of low-molecular-weight products were observed during the stationary phase in all experiments.

Table 2. Proportions (as \% of TCHO release) of HMWCHO released during exponential and stationary phase (growth conditions as for Table 1). Values are means $\pm \mathrm{SD}$, which are based on 8 measurements during the exponential phase, and 4 during the stationary phase; single values, for which no replicates were obtained, are also shown

\begin{tabular}{|c|c|c|c|c|}
\hline $\begin{array}{l}\text { Species } \\
\text { Medium }\end{array}$ & $f / 2 L L$ & $\mathrm{f} / 2 \mathrm{HL}$ & P-lim & $\mathrm{f} / 200$ \\
\hline \multicolumn{5}{|c|}{ Coscinodiscus granii } \\
\hline Exponential & $38 \pm 12$ & $44 \pm 17$ & $57 \pm 4$ & $31 \pm 11$ \\
\hline Stationary & $58 \pm 9$ & $68 \pm 12$ & $72 \pm 14$ & $76 \pm 3$ \\
\hline \multicolumn{5}{|c|}{ Stephanopyxis palmeriana } \\
\hline Exponential & $31 \pm 14$ & $33 \pm 16$ & $68 \pm 5$ & $39 \pm 12$ \\
\hline Stationary & $72 \pm 9$ & $75 \pm 19$ & $79 \pm 11$ & 97 \\
\hline \multicolumn{5}{|l|}{ Chaetoceros sp. 1} \\
\hline Exponential & $44 \pm 5$ & $38 \pm 6$ & $68 \pm 9$ & - \\
\hline Státionary & $50 \pm 6$ & $41 \pm 1$ & - & - \\
\hline \multicolumn{5}{|l|}{ Chaetoceros sp. 2} \\
\hline Exponential & $29 \pm 9$ & - & $66 \pm 9$ & - \\
\hline Stationary & 50 & - & 86 & - \\
\hline \multicolumn{5}{|c|}{ Nitzschia delicatissima } \\
\hline Exponential & $24 \pm 13$ & - & - & - \\
\hline Stationary & $60 \pm 13$ & 62 & $87 \pm 7$ & - \\
\hline \multicolumn{5}{|c|}{ Skeletonema costatum } \\
\hline Exponential & $20 \pm 11$ & - & - & - \\
\hline Stationary & $72 \pm 18$ & 68 & $74 \pm 9$ & - \\
\hline
\end{tabular}



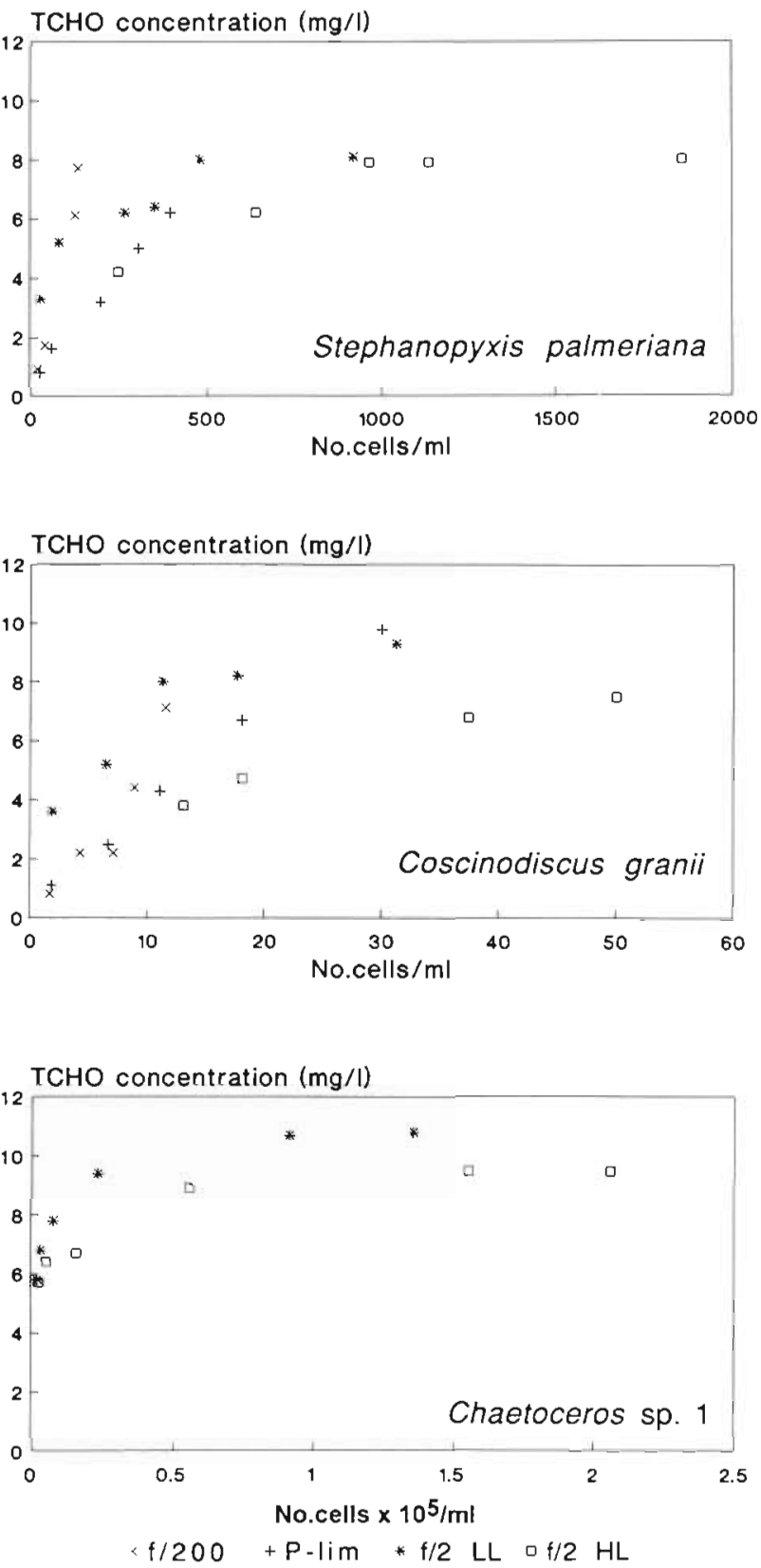

Fig. 2. Stephanopyxis palmeriana, Coscinodiscus granii, Chaetoceros sp. 1. Relations between total carbohydrate (TCHO) concentration ( $\mathrm{mg} \mathrm{l}^{-1}$ ) and cell concentration in different culture media. $\mathrm{f} / 2 \mathrm{LL}=\mathrm{f} / 2$ medium under low light; $\mathrm{f} / 2 \mathrm{HL}=\mathrm{f} / 2$ medium under high light; $\mathrm{f} / 200=\mathrm{f} / 200$ medium; $\mathrm{P} \mathrm{lim}=$ phosphorus limiting medium. See text for details of culture conditions

The results of the preliminary feeding experiment with mixed Temora longicornis and Pseudocalanus elongatus and addition of concentrated diatom HMW$\mathrm{CHO}$ are shown in Fig. 4. Feeding rate and the number of fecal pellets produced were significantly lower in experimental bottles with addition of the diatom HMWCHO

We then examined the effect of pure HMW dextran and diatom HMWCHO on feeding and egestion rate of Temora longicornis and Calanus helgolandicus. No influence of dextran addition on $C$. helgolandicus feeding was detected. In contrast, we found that $T$. longicornis ingestion rates were significantly lower ( $\mathrm{p}<0.01, t$-test between means) when exposed to dextran (Fig. 5), and the number of fecal pellets produced in the presence of dextrans and diatom HMWCHO was also lower (Fig. 5). T. longicomis produced pellets with mean length of $336 \pm 52 \mu \mathrm{m}$ and mean width of $54 \pm$ $10 \mu \mathrm{m}$. The size of fecal pellets varied under different experimental treatments and hence egestion rates in terms of the volume of fecal pellets produced per copepod per hour are given in Table 3 .

Feeding rates of Temora longicornis were then determined under 3 different treatments: food (Skeletonema costatum) was suspended in filtrate of the stationary $S$. costatum culture (Fig. 6a) and in diluted
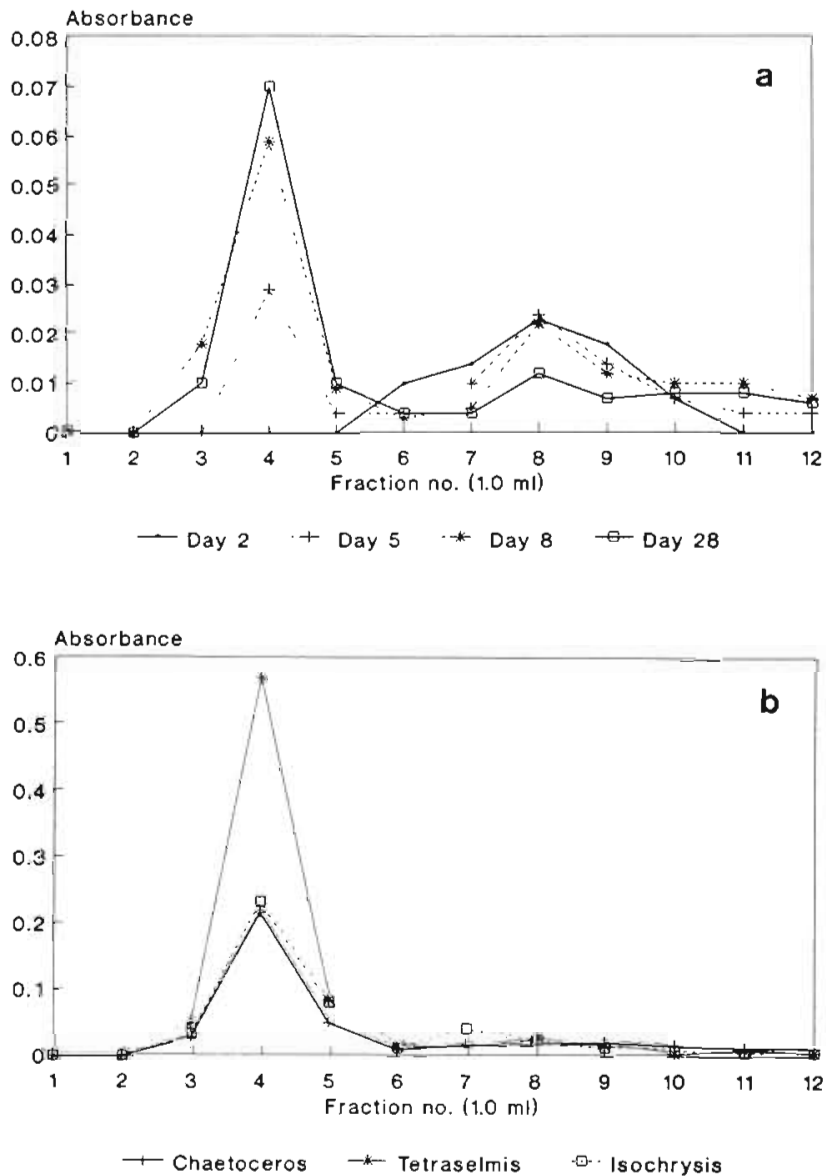

Fig. 3. (a) Sephadex gel-fractionation of Skeletonema costatum culture over time. (b) Sephadex gel-fractionation of stationary phase cultures of Chaetoceros sp. 1, Tetraselmis suecica and Isochrysis galbana 
$(50 \%)$ filtrate of exponentially growing and diluted $(50 \%)$ filtrate of stationary S. costatum culture (Fig. $6 b)$. While we found no effect of the addition of exponentially growing algal culture filtrate, $T$. longicomis ingested food at significantly $(\mathrm{p}<0.01, t$-test between means) lower rates in the presence of the stationary culture filtrate, both concentrated (Fig. 6a) and diluted (Fig. 6b).

\section{DISCUSSION AND CONCLUSIONS}

Extracellular release of organic matter by phytoplankton has been the subject of numerous studies during the last $20 \mathrm{yr}$, however, the significance and ecological role of this process are still matters of uncertainty (Wood \& van Valen 1990). Although Sharp (1977) concluded that there was no good evidence that
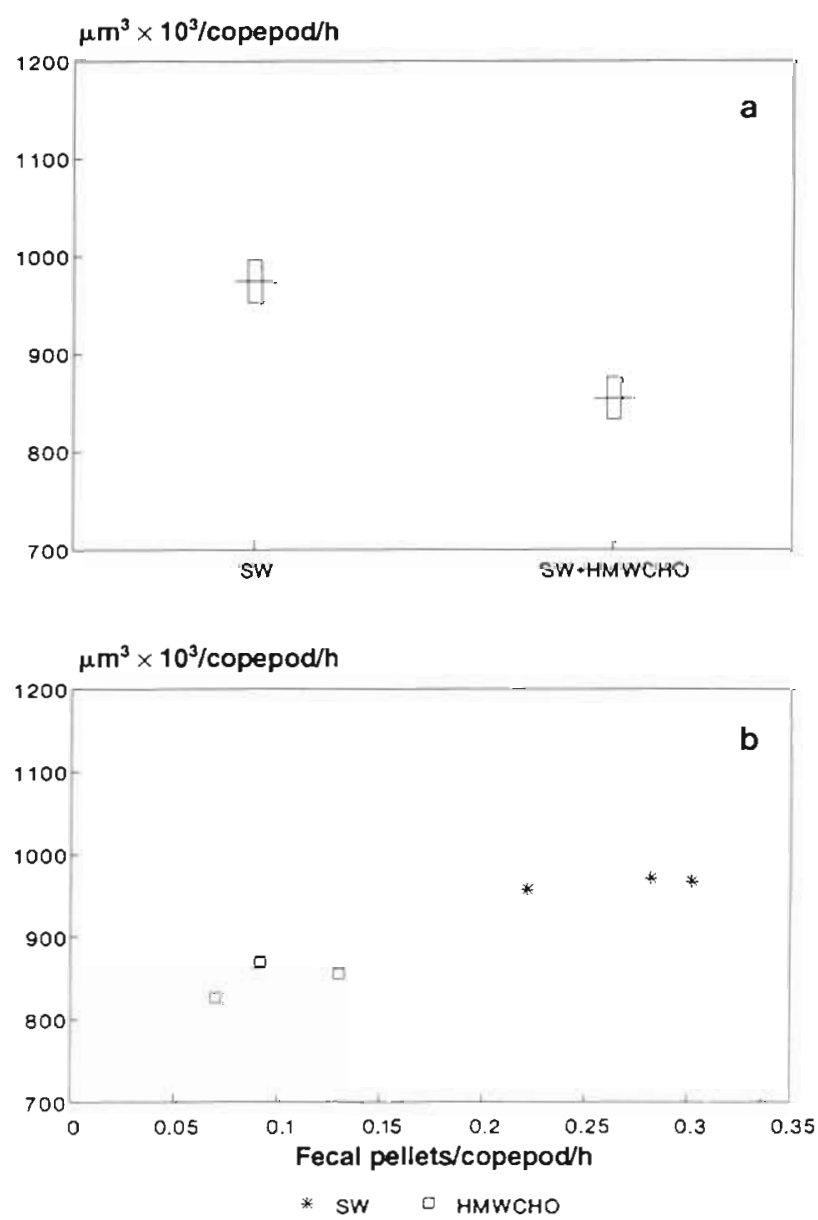

Fig. 4. Mixed copepods (Temora longicomis, Pseudocalanus elongatus) feeding on Thalassiosira weissflogii. The effect of HMWCHO concentrate from stationary phase Coscinodiscus granii culture on (a) feeding (mean $\pm \mathrm{SD}$ ) and (b) fecal pellet production
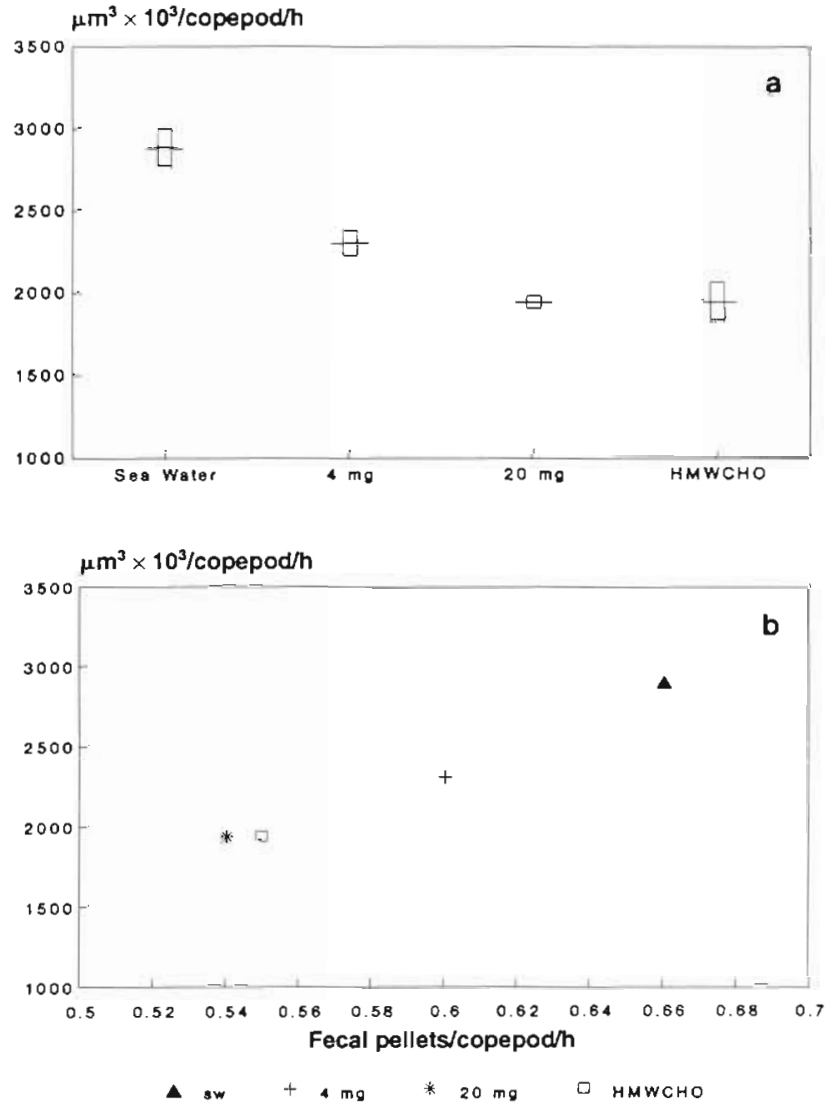

Fig. 5. Temora longicornis feeding on Thalassiosira weissflogii. Comparative effects of pure HMW dextran and HMW$\mathrm{CHO}$ diatom concentrate on (a) feeding (mean $\pm \mathrm{SD}$ ) and (b) egestion rate

healthy phytoplankton excrete organic matter, it is now generally accepted that extracellular release of organic compounds occurs during both exponential and stationary phases of growth (Myklestad et al. 1989). Extracellular release of organic matter has also been shown to occur in natural phytoplankton populations (Ittekkot et al. 1981, Lancelot 1983).

A wide variety of biochemical products have been found in phytoplankton exudates (Lancelot 1984), although there is still considerable uncertainty as to

Table 3. Temora longicornis. Egestion rates in relation to different additions of pure dextran and HMWCHO (mean, with standard deviation in parentheses)

\begin{tabular}{|lc|}
\hline Treatment & $\begin{array}{c}\text { Egestion rate } \\
\left(\times 10^{6} \mu \mathrm{m}^{3} \text { copepod }^{-1} \mathrm{~h}^{-1}\right)\end{array}$ \\
\hline Seawater control & $0.50(0.10)$ \\
$4 \mathrm{mg}$ dextran & $0.46(0.09)$ \\
20 mg dextran & $0.33(0.07)$ \\
HMWCHO & $0.45(0.10)$ \\
\hline
\end{tabular}



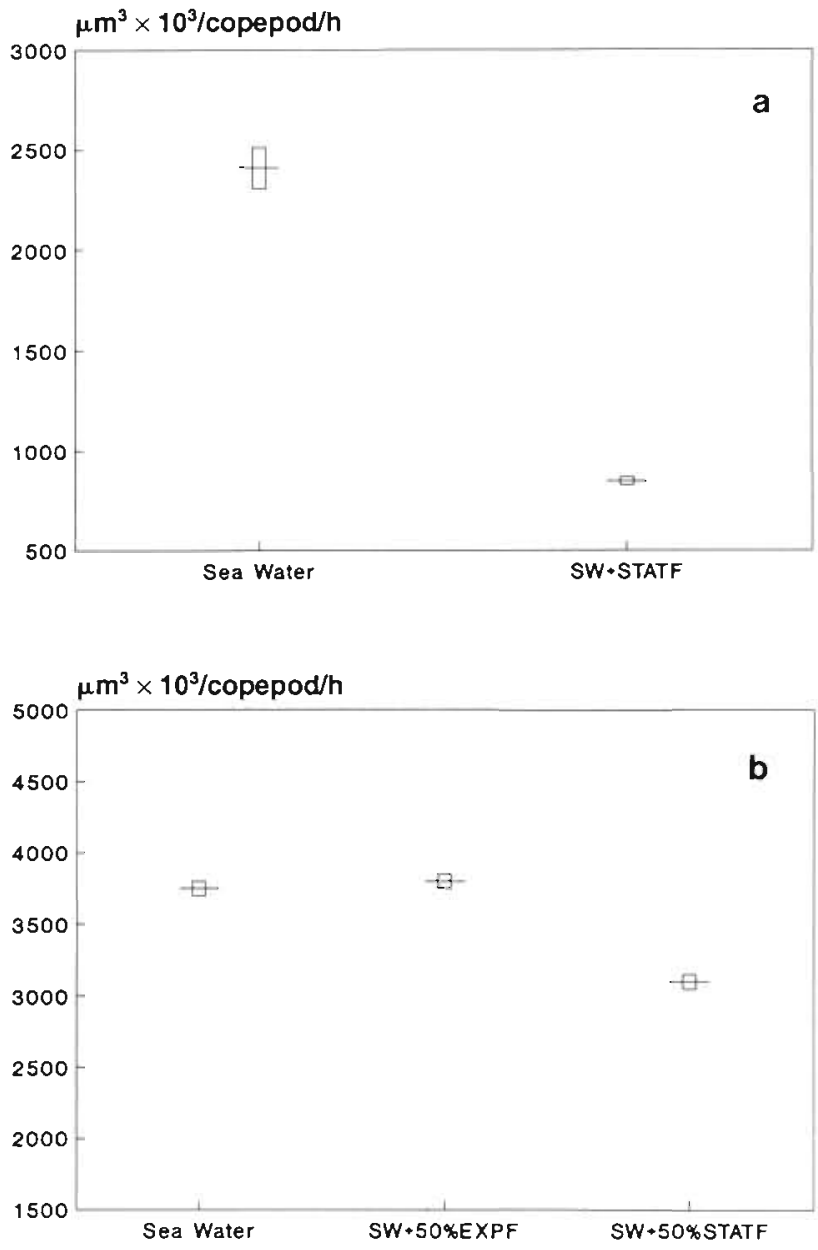

Fig. 6. Temora longicornis feeding on Skeletonema costatum. (a) Effect of cell-free stationary culture medium from $S$. costatum (STATF) on feeding rate (mean \pm SD). (b) Effect of diluted $(50 \%)$ cell-free culture medium from exponentially growing (EXPF) and stationary (STATF) culture of $S$. costatum on feeding rate (mean $\pm \mathrm{SD}$ )

the precise nature of material released. Some studies have indicated that exudates from actively growing phytoplankton are predominantly low-molecularweight $(<700)$ compounds (Sondergaard \& Schierup 1982). Møller Jensen (1983) reported that extracellular products with low MW (<900) constituted 69 to $100 \%$ before, and 39 to $56 \%$ during, the spring diatom bloom. In contrast, studying freshwater phytoplankton, Nalewajko \& Schindler (1976) found low-molecularweight $(<1500)$ material representing less than $10 \%$ of total extracellular products in all cases, even after incubation times of only $1 \mathrm{~h}$. Similarly, Lancelot (1984) showed that the amount of small excreted molecules (MW < 500) was always lower than extracellular polymers and suggested that polysaccharides were the main excreted products of natural phytoplankton. Moreover, Ittekot et al. (1981) measured large amounts of carbohydrates released into seawater during a phytoplankton bloom and more than $75 \%$ consisted of combined carbohydrates. They concluded that $\mathrm{CHO}$ monomers were not the major excretion products of phytoplankton but were formed mainly by in situ hydrolysis of dissolved combined $\mathrm{CHO}$. On the other hand, it has been suggested that rapid bacterial uptake of low-molecular-weight products and subsequent release of high-molecular-weight compounds by bacteria may be responsible for the predominance of the latter in natural waters (Chrost \& Faust 1983, Gomes et al. 1991)

Our results indicate an increased significance of HMWCHO release in the stationary phase of culture growth, and also during exponential growth in P-limited medium. We did not follow the presence of bacteria during our experiments and it remains unclear to what extent the shift towards HMWCHO in stationary cultures is due to bacterial uptake of smaller molecules

Smetacek (1985) proposed that mucus production, flocculation and mass sinking represent an important part of diatom survival strategy from a surface growing stage to a benthic or deep-water resting stage. Declining growth in conjunction with mucus secretion presumably leads to increasing sinking rate and aggregate formation. Indeed, Kiørboe et al. (1990) have demonstrated that stickiness of diatom cells may increase by more than 2 orders of magnitude as cell growth ceases, while Alldredge \& McGillivary (1991), who studied attachment probabilities of marine snow, found the highest probabilities of aggregate formation for diatom flocs. We suggest that production of mucus, which is predominantly carbohydrate, may act as a grazer deterrent enabling diatoms to maintain their biomass and to conserve essential elements (N, P, Si) which are in short supply. Increased HMWCHO production during stationary growth phase, and also in Plimited environments, enhances the stickiness of diatom cells and consequently increases the attachment probability leading to macroaggregate formation.

The grazing potential of copepods has long been viewed as a major factor controlling seasonal diatom blooms in coastal waters (Cushing 1989, Bathmann et al. 1990). There are indications that the age of phytoplankton cultures may negatively affect copepod grazing (Mullin 1963). Cowles et al. (1988) demonstrated that copepods selectively ingested faster growing algal cells when a mixture of fast and slow growing diatom cells was offered as food. They concluded that physiological differences between algal cells were critical for selection and suggested that copepods may use extracellular gradients in exudates to discriminate between the 2 algal types. The grazing rates of the copepod spe- 
cies used in the present experiments, under control conditions, are typical of those reported for these species, using similar experimental techniques, feeding on natural particulate material in situ. For example, for Pseudocalanus elongatus, Harris (1982) measured rates ranging from 21.9 to $30.4 \times 10^{6} \mu^{3}$ copepod $^{-1}$ $\mathrm{d}^{-1}$, and for Temora longicornis, $\mathrm{O}^{\prime}$ Connors et al. (1980) reported maximum ingestion rates in the range from 20.6 to $71.8 \times 10^{6} \mu \mathrm{m}^{3}$ copepod ${ }^{-1} \mathrm{~d}^{-1}$.

Our study demonstrates that copepod feeding, under the experimental conditions used, employing species characteristic of the Adriatic, is inhibited by HMWCHO diatom exudate as well as stationary (aged) culture filtrate. The feeding rate of Temora longicomis was also adversely affected by the presence of pure HMW dextran used as a model substance. This implies that inhibition may be at least partly mechanically mediated. It has been demonstrated that during phytoplankton blooms the thickening behaviour of algal polysaccharides may change rheological properties (Jenkinson 1986), and the study of bacterial extracellular polysaccharides indicated high apparent viscosity increasing markedly with bacterial concentration (Anton et al. 1988). Jenkinson (1989) suggested that increased viscosity may even kill fish in some plankton blooms due to the high energy requirement for pumping the more viscous liquid. Copepods use comparatively more energy for swimming than some other zooplankton (Davenport \& Trueman 1985). Increased viscosity due to polysaccharides may reduce turbulence (Jenkinson 1990) and consequently encounter rate, leading to lower ingestion rates. In more viscous and less turbulent environments, copepods would require higher energy output when feeding (Granata \& Dickey 1991).

Our experiments indicate that copepod feeding is more strongly inhibited by diatom HMWCHO exudates from senescent cells than by an equivalent concentration of the pure HMW dextran (Fig. 5) pointing to an additional response to chemical stimuli of algal exudates. There are several studies demonstrating rejection or avoidance of some dinoflagellate prey by copepods (Huntley 1982, Huntley et al. 1986, Gill \& Harris 1987, Uye \& Takamatsu 1990). These authors also suggested that reduced grazing pressure was an important factor in development of monospecific dinoflagellate blooms. Our results suggest that diatom cells may also produce distasteful compounds. Inhibition of copepod feeding on diatoms may have important repercussions for spring phytoplankton dynamics in temperate waters. The potential of herbivorous copepods to control the development of diatom blooms and production of large quantities of mucus is thus dependent on the presence of sufficient copepod stock during the time of the exponentially growing diatom population, when the cells produce deterrent mucus only in limited quantities. Reduction of copepod feeding rates due to algal exudates in transitional and stationary phase will allow diatom stocks to persist and continue producing mucus. Eventually, this process may enhance macroaggregate formation and mass sedimentation.

There is as yet no direct evidence from the field that these processes are crucial for the massive mucus accumulations in the Adriatic Sea during recent years. However, monitoring of the zooplankton in the northern Adriatic (Anon. 1991) has indicated substantially lower late winter-spring copepod stocks during years when mucus accumulated. Future work should establish whether combining HMWCHO production rates for Adriatic phytoplankton species with observed algal biomass in the area (e.g. Anon. 1991) can account for comparable production figures to the field-estimated mucus biomass (e.g. Stachowitsch et al. 1990).

Acknowledgements. This work was financially supported by a grant from the Commission of the European Communities (CI1/0081). Special thanks are due to Derek Harbour for isolating diatom species, to Bob Head and Paul Tranter for laboratory assistance and the crew of RV 'Squilla' for collecting live plankton samples

\section{LITERATURE CITED}

Alldredge, A. L., McGillivary, P. (1991). The attachment probabilities of marine snow and their implications for particle coagulation in the ocean. Deep Sea Res. 38: 431-443

Alldredge, A. L., Silver, M. W. (1988). Characteristics, dynamics and significance of marine snow. Prog. Oceanogr. 20: $41-82$

Anon. (1991). Campagna di ricerca sullo stato chimico, fisico e biologico delle acque dell'Alto Adriatico, in relazione al fenomeno di formazione degli ammassi gelatinosi. Osservatorio Alto Adriatico. Prog. Rep. Allegato A: $31 \mathrm{pp}$

Anton, J., Meseguer, I., Rodriguez-Valera, F. (1988). Production of an extracellular polysaccharide by Haloferax mediterranei. Appl. environ. Microbiol. 54: 2381-2386

Bathmann, U. V., Noji., T. T., von Bodungen, B. (1990). Copepod grazing potential in late winter in the Norwegian Sea - a factor in the control of spring phytoplankton growth. Mar. Ecol. Prog. Ser. 60: 225-233

Boalch, G. T., Harbour, D. S. (1977). Unusual diatom off the coast of south-west England and its effect on fishing. Nature 269: 687-688

Cabrini, M., Fonda Umani, S., Honsell, G. (1992). Mucilaginous aggregates in the Gulf of Trieste (northern Adriatic Sea): analysis of the phytoplanktonic communities in the period June-August 1989. Sci. total Environ. (Suppl.) 1992: $557-568$

Chrost, R. J., Faust, M. A. (1983). Organic carbon release by phytoplankton: its composition and utilization by bacterioplankton. J. Plankton Res. 5: 477-493

Cushing, D. H. (1989). A difference in structure between ecosystems in strongly stratified waters and those that are only weakly stratified. J. Plankton Res. 11:1-13

Cowles, T. J., Olson., R. J., Chisholm, S. W. (1988). Food selec- 
tion by copepods: discrimination on the basis of food quality. Mar. Biol. 100: 41-49

Davenport, J., Trueman, E. R. (1985). Oxygen uptake and buoyancy in zooplankton organisms from the tropical Eastern Atlantic. Comp. Biochem. Physiol. 81A: 857-863

Decho, A. W. (1990). Microbial exopolymer secretions in ocean environments: their role(s) in food webs and marine processes. Oceanogr. mar. Biol. A. Rev. 28: 73-153

Fanuko, N., Turk, V. (1990). The oceanologic properties of the seawater in the Gulf of Trieste before and during the 'mare sporco' phenomenon (summer 1988). Boll. Oceanol. teor. appl. 8: 3-11

Fogg, G. E. (1983). The ecological significance of extracellular products of phytoplankton photosynthesis. Botanica mar 26: $3-14$

Fonda Umani, S., Franco., P., Ghiradelli., E., Malej, A. (1993). Outline of oceanography and the plankton in the Adriatic Sea. In: Colombo, G., Ferrari, I., Ceccherelli, V. U., Rossi, R. (eds.) Population dynamics of marine organisms. Olsen \& Olsen, Fredensborg, p. 347-365

Fonda Umani S., Ghirardelli, E., Specchi, M. (1989). Gli episodi di 'mare sporco' nell'Adriatico dal 1729 ai giorni nostri. Reggione Autonoma Friuli-Venezia Giulia. Direzione Regionale Ambiente, Trieste

Gill, C. W., Harris, R. P. (1987), Behavioural responses of the copepods Calanus helgolandicus and Temora longicomis to dinoflagellate diets. J. mar. biol. Ass. U.K. 67: 785-801

Gomes, H. R., Plant, A., Goes, J. I., Parulekar, A. H. (1991). Heteroptrophic utilization of extracellular products of phytoplankton in a tropical estuary. J. Plankton Res. 13: 487-498

Granata, T. C., Dickey, T D. (1991). The fluid mechanics of copepod feeding in a turbulent flow. Prog. Oceanogr. 26: $243-261$

Guillard, R. R. L., Ryther, J. H. (1962). Studies of marine planktonic diatoms. I. Cyclotella nana Hustedt and Detonula confervacea (Cleve) Gran. Can. J. Microbiol. 8: 229-239

Harris, R. P. (1982). Comparison of the feeding behaviour of Calanus and Pseudocalanus in two experimentally manipulated enclosed ecosystems. J. mar. biol. Ass. U.K. 62: $71-91$

Herndl, G., Karner, M., Peduzzi, P. (1992). Floating mucilage in the northern Adriatic Sea: the potential of a microbial ecological approach to solve the 'mystery'. Sci. total Environ. (Suppl.) 1992: 525-538

Huntley, M. E. (1982). Yellow water in La Jolla Bay, California, July 1980. Il. Supression of zooplankton grazing. J exp. mar. Biol. Ecol. 63: 81-91

Huntley, M., Sykes, P., Rohan, S., Marin, V. (1986). Chemically-mediated rejection of dinoflagellate prey by the copepods Calanus pacificus and Paracalanus parvus mechanism, occurrence and significance. Mar. Ecol. Prog Ser. 28: 105-120

Ittekkot, V., Brockmann, U., Michaelis, W., Degens, E. T. (1981). Dissolved free and combined carbohydrates during a phytoplankton bloom in the northern North Sea. Mar Ecol. Prog. Ser. 4: 299-305

Jenkinson, I. R. (1986). Oceanographic implication of nonnewtonian properties found in phytoplankton cultures Nature 323: 435-437

Jenkinson, I. R. (1989). Increase in viscosity may kill fish in some blooms. In: Okaichi, T., Anderson, D. M., Nemoto, $T$ (eds.) Red tides: biology, environmental science, and toxicology. Elsevier Science Publishing, New York, p. $435-438$

Jenkinson, I. R. (1990). Rheological structure in bulk seawater. In: Oliver, D. R. (ed.) Third European Rheology Con- ference. Elsevier Applied Science, London, p. 247-251

Kiørboe, T., Andersen., K. P., Dam, H. G. (1990). Coagulation efficiency and aggregate formation in marine phytoplankton. Mar. Biol. 107: 235-245

Lancelot, C. (1983). Factors affecting phytoplankton extracellular release in the Southern Bight of the North Sea. Mar. Biol. 12: 115-121

Lancelot, C. (1984). Extracellular release of small and large molecules by phytoplankton in the Southern Bight of the North Sea. Estuar. coast. Shelf Sci. 18: 65-77

Malej, A., Faganeli, J. (1988). Il fenomeno del 'mare sporco' nell'Adriatico. In: Brambati, A. (ed.) CNR Progetto Strategico Oceanografia e Tecnologie Marine. Ricci, Trieste, p. $47-49$

Marchetti, R., Iacomini, M., Torri., G., Focher, B. (1989) Caratterizzazione preliminare degli essudati di origine fitoplanctonica raccolti in Adriatico nellestate 1989. Acqua-Aria 8: 883-887

Marin, V., Huntley, M. E., Frost, B. W. (1986). Measuring feeding rates of pelagic herbivores: analysis of experimental design and methods. Mar. Biol. 93: 49-58

Moller Jensen, L. (1983). Phytoplankton release of extracellular organic carbon, molecular weight composition, and bacterial assimilation. Mar. Ecol. Prog. Ser. 11: 39-48

Molin, D., Guidoboni, E., Lodovisi, A. (1992). Mucilage and the phenomena of algae in the history of the Adriatic: periodization and the anthropogenic context (17th-20th centuries). Sci. total Environ. (Suppl.) 1992: 511-524

Mullin, M. M. (1963). Some factors affecting the feeding of marine copepods of the genus Calanus. Limnol. Oceanogr. 8: $239-250$

Myklestad, S., Holm-Hansen, O., Varum, K. M., Volcani, B. E. (1989). Rate of release of extracellular amino acids and carbohydrates from the marine diatom Chaetoceros affinis. J. Plankton Res. 11:763-773

Nalewajko, C., Schindler, D. W. (1976). Primary production, extracellular release, and heterotrophy in two lakes in the ELA, northwestern Ontario. J. Fish. Res. Bd Can. 33: $219-226$

O'Connors, H. B., Biggs, D. C., Ninivaggi, D. V. (1980). Particle-size-dependent maximum grazing rates for Temora longicornis fed natural particle assemblages. Mar. Biol. 56: $65-70$

Posedel, N., Faganeli, J. (1991). Nature and sedimentation of suspended particulate matter during density stratification in shallow coastal waters (Gulf of Trieste, northern Adriatic). Mar. Ecol. Prog. Ser. 77: 135-145

Revelante, N., Gilmartin, M. (1991). The phytoplankton composition and population enrichment in gelatinous 'macroaggregates' in the Northern Adriatic during the summer of 1989. J. Plankton Res. 146: 217-233

Riebesell, U. (1991). Particle aggregation during a diatom bloom. I. Physical aspects. Mar. Ecol. Prog. Ser. 69: $273-280$

Sharp, J. H. (1977). Excretion of organic matter by phytoplankton: do healthy cells do it? Limnol. Oceanogr. 22: 381-398

Smetacek, V. S. (1985). Role of sinking in diatom life-history cycles: ecological, evolutionary and geological significance. Mar. Biol. 84: 239-251

Sondergaard, M., Schierup, H.-H. (1982). Release of extracellular organic carbon during a diatom bloom in Lake Mosso: molecular weight fractionation. Freshwat. Biol. 12: $313-320$

Stachowitsch, M., Fanuko, N., Richter, M. (1990) Mucus aggregates in the adriatic Sea: an overview of stages and occurrences. P.S.Z.N. I: Mar. Ecol. 11. 327-350 
Strickland, J. D. H., Parsons, T. R. (1968). A practical handbook of sea water analysis. Bull. Fish. Res. Bd Can. 167: $1-311$

Uye, S., Takamatsu, K. (1990). Feeding interactions between planktonic copepods and red-tide flagellates from Japanese coastal waters. Mar. Ecol. Prog. Ser. 59: 97-107

This article was submitted to the editor
Wood, M. A., van Valen, L. M. (1990). Paradox lost? On the release of energy-rich compounds by phytoplankton. Mar. Microb. Food Webs 4: 103-116

Yoshida, M. (1991). Function of the carbohydrates in contact site a glycoprotein of Dictyostelium discoideum affected by tunicamycin. Comp. Biochem. Physiol. 98B: 563-568

Manuscript first received: March 17, 1992

Revised version accepted: March 22, 1993 